\title{
Like Bamboo Shoots after the Rain
}

\section{Citation}

Gordon, Andrew. 2011. Like bamboo shoots after the rain: The growth of a nation of dressmakers and consumers. In The Historical Consumer: Consumption and Everyday Life in Japan, 1850-2000, ed. Penelope Francks and Janet Hunter, 56-78. Hampshire, UK: Palgrave Macmillan.

\section{Permanent link}

http://nrs.harvard.edu/urn-3:HUL.InstRepos:10436346

\section{Terms of Use}

This article was downloaded from Harvard University's DASH repository, and is made available under the terms and conditions applicable to Other Posted Material, as set forth at http:// nrs.harvard.edu/urn-3:HUL.InstRepos:dash.current.terms-of-use\#LAA

\section{Share Your Story}

The Harvard community has made this article openly available.

Please share how this access benefits you. Submit a story.

\section{Accessibility}




\title{
Like Bamboo Shoots after the Rain
}

\author{
The Growth of a Nation of Dressmakers and Consumers
}

\section{Andrew Gordon}

\section{Introduction}

The female consumer stands - in advertisements quite literally - as one of the most prominent symbols of Japan's astonishing post-war economic rise to global prominence. Even in the impoverished aftermath of war, her smiling figure beckoned to her compatriots to share in the 'bright life' enabled by purchase of the fruits of modern industry. One of the goods she bought and used with greatest intensity - whether measured in the rate of diffusion or the daily hours of use - was the sewing machine. Perhaps because of the difficulty of neatly defining its economic or social character, the sewing machine is a product often overlooked in standard accounts of Japan's post-war consumer revolution. It was at once an object of consumer desire and a producer good used to make clothing not only for the family but also for the commercial market. But for this very reason I see the extraordinary spread of the sewing machine as both harbinger and example of a broader story: the heroines of Japan's post-war consumer revolution brought to the task of managing the household and filling it with all manner of goods a professional spirit not unlike that of their male counterparts, the 'salarymen' who designed or made or sold these products in Japan and around the world.

Even before World War II, as many as one in ten families owned a sewing machine. It had a distinctive profile of use: mainly in the home, mainly by women, in 
ways that positioned it as both a consumer and producer good and as a possession connected to a Western-oriented modern life. Its greatest selling point beyond speed was the ability to produce tight-locked stitches. But this made it poorly suited to fabrication of traditional Japanese garments whose outer and inner pieces had to be loosely chainstitched so they could easily be taken apart for laundering. From early in the twentieth century, women used the sewing machine to make Western-style clothes both for family members and in some cases for sale to neighbours or on piece-work consignment.

From this solid pre-war foundation, domestic purchase of sewing machines soared in the first two post-war decades. As early as 1953, according to estimates by the Ministry of International Trade and Industry, annual domestic sales reached 800,000 units, while dress shops and sewing schools sprouted 'like bamboo shoots after the rain' (Mishin kōgyō, 1954, p. 25; Koizumi, 2000, p. 42). As Penelope Francks' paper in this volume suggests, the spread of Western dress for women had been limited until the 1930s, and this had inhibited the spread of the sewing machine. Before World War II the diffusion rate in Japan lagged noticeably compared to places with considerably lower incomes per capita (Gordon, 2011, ch 2). But in the 1950s and 1960s, the bottleneck was broken; the near universal turn of women in Japan to Western dress both caused and resulted from the sewing machine's diffusion. The good became a key link in a feedback loop connecting home sewing, new fashion trends, and the consuming household. Its story opens a window on to the era when the consumer became a truly dominant figure in the practice and the self-understanding of Japanese life, and women became truly entrenched as the managers of consumer life. 


\section{Long hours of sewing: the time allocation of the professional housewife}

The sewing machine can be a tool for historical study of consumer and family life worldwide, but it is particularly useful for such an inquiry in relation to Japan because of the unusually long hours that Japanese women devoted to sewing. Several surveys of the early 1950s, both community studies and national samples, found that married urban women of both working- and middle-class families typically devoted nearly three hours each day to home sewing (Kawasaki rōdō shi hensan iinkai, 1987, p. 200; Rōdōshō, fujin shōnen kyoku, 1952). As a comparative point of reference, surveys from the United States find that already by the 1920 s women averaged only one hour a day of needlework. French women in the immediate post-war years stood somewhere between: according to a 1948 survey, they devoted one hour to ninety minutes daily to 'sewing, mending, knitting, and wardrobe management' (a more capacious definition than that used in Japanese surveys) (Vanek, 1973; Stoetzel, 1948, pp. 52-56). A 1949 study of 'working class wives in London' found an average of merely 20 minutes per day given over to 'sewing' (Mason, 1949, p. 372). These totals in all cases excluded home-based commercial sewing. Other surveys make it clear that home-based women in Japan - as elsewhere - also undertook considerable sewing for the market. In the two decades following the war, for various purposes but for many hours, all over the nation women sewed.

Some of this needlework was certainly done by hand, but home sewing became an increasingly mechanised undertaking as millions of women bought sewing machines. Whether by hand or machine, women in Japan were sewing so very much due to a dynamic interaction of local and global practice. Although time studies are not available 
to offer a rigorous comparison, it seems certain that already in pre-modern times the need to unstitch and re-stitch garments in order to wash them made home sewing a particularly time-intensive activity. From Meiji times through the 1950s, as the practice of dress and sewing shifted from Japanese to Western modes, the efforts of salesmen, the exhortations of civilian reformers and state officials, and the needs and desires of millions of women would together reinforce the time-consuming practice of fabricating dress at home with sewing machines.

Insofar as one understands consumption in modern societies as an act that offers pleasure and satisfies wants as well as basic material needs, it is noteworthy that a 1959 survey revealed that in addition to performing needlework under the rubric of 'household work', women in Japan ranked sewing their third most popular 'free time' activity after reading and listening to the radio. Asked how they used their average of two hours of free time daily, about half of the women said they read, just over one quarter listened to radio, and another one quarter sewed. Playing with children was the primary activity of only 13 per cent (Rōdōshō, fujin shōnen kyoku , 1959, pp. 2-19). ${ }^{1}$ During the years of the take-off of mass consumption of branded industrial goods, as they stitched both for family consumption and for the market, both as 'housework' and for pleasure, Japanese women in the 1950s and 1960s constituted a nation of seamstresses and dressmakers.

This activity was part of the daily routine of the 'professional housewife' in her heyday. She was the Japanese incarnation of the full-time housewife who emerged to prominence in capitalist societies around the world in the mid-twentieth century. This label is at first glance an oxymoron. Professionals are those who work for pay, while the labour of the female household manager is unpaid. But I use it, following others such as

\footnotetext{
${ }^{1}$ Multiple answers were accepted so the total exceeded 100 per cent.
} 
Suzanne Vogel, because it better renders the Japanese language expression sengyō shufu than the usual translation of 'full-time housewife' (Vogel, 1978, pp. 16-43). The character for gyō conveys the sense of occupation or job, and the term sengyō means 'specialised enterprise or occupation'. A sengyō shufu not only works 'full-time' but does so with a professional commitment to being a housewife on a par with the workplace professionalism of her salaried husband.

The concept and the social role of housewife (shufu) came into being from the late nineteenth century through wartime. The term carried to a mass audience the sense of the good wife and wise mother constructed in the ideology of late Meiji times. This understanding of the housewife was given wide currency in the inter-war era through monthly magazines, most famously The Housewife's Companion (Shufu no Tomo). The term 'professional housewife' came into common use only after World War II; through the era of recovery and high-speed growth it came to be understood as the ideal role for a married woman (Kunihiro, 2001, pp. 4-6; Ochiai, 1994). The housewife's vocational training and obligations extended more widely than ever, from management of home finances - and sometimes a stint supplementing family income as a home-worker - to housework, child rearing and education management. It included 'care for the physical, emotional, and developmental needs of the family' through tasks such as cooking and sewing (Vogel, 1978, p. 17). By examining the ways in which the sewing machine became the everyday tool of Japan's every-woman, we gain insight into the life of the 'professional' housewife and the dynamics of her endurance as a national ideal at the centre of the consumer economy. 


\section{What women wore: the end to the two-layered life}

In 1957 the prominent cultural critic, Ōya Sōichi, declared in a newspaper column that a 'dress revolution' had brought an end to Japan's 'two-layered life' ("Nihonjin” Asahi shinbun 13 January 1957, cited in Nakayama, 1987, p. 462). This term had come into wide use in the 1920 s to describe and usually to lament a society in which daily life was torn between modes of housing, clothing and cooking identified as 'Japanese' and those defined as 'Western' (washitsu/yōshitsu; wafuku/yōfuku, washoku/yōshoku etc). ${ }^{2}$

Because the sewing machine had long been understood as a tool suited only for the fabrication of Western clothing, the swift post-war shift to this mode of dress unleashed a flood of demand for it. By 1960 as many as 72 per cent of Japan's 20 million households possessed one, making it the second most widely owned consumer machine, after the radio at 89 per cent (and well ahead of the television at 55 per cent) (Nihon mishin kyōkai, 1961, p. 7).

Of course, this revolution in consumer life did not come immediately with the war's end. For one year at least, the dress options of city women were constrained by scarcity and rationing, and they continued to wear the trousers called monpe, adopted during wartime through a complex process of government and civic promotion mixed with improvisation on the ground. Only from 1949, with the recovery of domestic textile production, did significant supplies of fabric become available, and fabric rationing did not end until 1951 (Nakayama, 1987, pp. 455-56; Yoshimoto, 2004, p. 30). But even in the face of scarce fabric and rationing, change in clothing practice was already underway

\footnotetext{
2 Penelope Francks' essay on 'Kimono Fashion' for this volume persuasively demonstrates the resilience and significance of the 'Japanese' side of this two-layered life in prewar times.
} 
in the form of a rush by women to put on Western dress. As one compelling retrospective essay described the situation:

[At first] the situation for clothing, food, shelter, was beyond impossible. I believe it was around the start of summer the year after the defeat when it became possible to survive, still with extreme difficulty, starting from food, to shelter and clothing. Because, as it started to get hot, women changed from monpe to skirts....By 1948, it was clear that women's fashion [in Tokyo] had turned to the skirt, blouse, and some dabs of rouge (Yoshida, 1955, pp. 140-42).

Kon Wajirō, a renowned ethnographer of Japan's modern daily life since the 1920s, wrote that in the summer of 1950 'I travelled through farm villages from Kansai to Tōhoku. What surprised me was that in whatever remote mountain valley, the women who gathered were almost all in Western dress.' Even the agricultural cooperatives were selling fabrics for Western wear; simple blouses, skirts, one-piece dresses, and new sewing schools had already appeared (Inoue, 2001, pp. 239-40; Kon, 1967, p. 130). Kon exaggerated the speed and scope of the shift. During the summer of his farm visits, the Yomiuri newspaper conducted a nationwide poll and found that 61 per cent of respondents still wore both Western and Japanese dress, while 29 per cent had turned completely to Western wear. But even these totals represent a sharp change from pre-war or wartime surveys.

The sources of new fashions in city, town, and country among women of all ages were various. They included patterns featured in the ever-popular women's magazines, as well as the outfits worn by the 'pan-pan' (girlfriends or prostitutes to American GIs). As early as 1946, 'stylebooks' featuring patterns and instructions on how to make 
Western wear began to sell in great numbers, presenting eager readers with the latest in American trends. They conveyed a complicated mix of desire and defensiveness, and a non-linear course of change. The August 1947 founding issue of one of them, Amerikan Fasshon (American Fashion), acknowledged that 'with new fabrics or accessories so difficult to obtain, we must resign ourselves for some time to the need to make do and improvise with whatever we have at hand'. In addition, fashion writers faced a tension between Western styles and Japanese bodies. A certain skirt was said to 'be a problem for Japanese to wear'. A certain chemise dress was 'a look very difficult for Japanese to achieve, but what a free and easy way of dressing it is!' The magazine admitted frankly to readers that they were selling naught but dreams: 'wearing this sort of bold dress to a dinner or dance in today's Japan is unimaginable, but even the fantasy offers pleasure' (Nakayama, 1987, pp. 456-57).

But within a few years, large numbers of women were able to act out their fashion fantasies. Introduced via the United States, Christian Dior's 'New Look' long skirts of 1947 took off in Japan in 1948. From 1953, French designers led by Dior began to introduce their new spring lines in person in Tokyo, and over the following years trends in women's wear in Japan were integrated into a global world of fashion. As this happened, the path from Paris to the Tokyo cat-walk, and then to the wardrobes of millions of women, ran less through garment factories and stores with racks of readymade dress than through the hands of home-based family sewers and dressmakers. This path is reflected in the results of a 1953 survey conducted by researchers at Chūō University, which asked 'how do you learn of the latest fashions?'. Almost nobody mentioned department stores. A clear plurality, 33 per cent, replied 'from stylebooks'. 
These women were either making the clothes themselves or bringing the patterns to a dressmaker. In a literate nation of voracious readers, the role of print media was huge: second to stylebooks stood fashion magazines, the source for 25 per cent of the women, followed by newspapers at 15 per cent (Nakayama, 1987, pp. 458-59). Underlying and enabling this rapid change of clothes were the spread of new materials, especially nylon and other synthetic fabrics, and the spread of a machine which also moved from object of desire to familiar tool for millions of women sewing at home, whether for themselves and their family or for neighbours and strangers.

In sum, despite periodic 'kimono revivals' much celebrated by nostalgic commentators, including a short-lived meisen revival, women did not return to a life centred on wafuku after World War II. ${ }^{3}$ They moved from monpe through second-hand American surplus goods to their own fabrication of Western dress. Through the mediation of monpe they had in fact begun to wear trousers earlier than women in the West (Nakayama, 1987, p. 456). The reasons for the triumph of Western dress were several and related. It was gaining adherents at a rapid pace already in the 1930s. During wartime, the dynamics of officially promoted dress reform and the decisions of women to adopt monpe eroded the ground on which post-war advocates of a reformed Japanese dress might have stood (Gordon, 2011, chs. 5-6). In addition, as Japan's mainly American occupiers proved themselves for the most part not the demonic figures of wartime propaganda, and as they brought attractive promises of democracy and peace, the appeal was profound of cultural forms - dress included - which had long been associated in Japan with America and modern life.

\footnotetext{
${ }^{3}$ On meisen, see Francks essay in this volume.
} 
The early post-war years in these ways put in place a feedback loop between home sewing, new fashion trends, and the consuming and producing household. New domestic producers and new modes of women's dress made the sewing machine both available and indispensable, while mastery of this good reinforced the place of women as managers of post-war consumer life. A boom in sewing education built on pre-war and wartime foundations to spread a high level of skill at sewing and dressmaking to a remarkably high proportion of women. Often pursued and understood as a form of bridal training, these skills fostered the ascendance of the professional housewife in society and culture.

\section{Training a nation of dressmakers}

As women moved from monpe to the 'one-piece' dress, sewing education became a big business, and young women were its primary consumers. Some studied so they could fashion their own clothes from stylebooks. Those who purchased order-made wear supported a burgeoning population of 'Western dress shops' that relied on a growing mass of dressmakers. In Tokyo, the number of such stores rose from 1300 in 1943 to 15,000 in 1955 , meaning the city boasted a density of one dress shop for every 120 households (Nihon tōkei kyōkai, 1987, p. 172). This total of dress shops in Tokyo alone was roughly the same as the number of post-offices in the entire country. 90 per cent of those who sewed for these stores were women working on contract from their homes or in small workshops attached to some stores. The commercial production and sale of women's wear in the 1950s relied more on such dispersed networks of women sewing at home than on specialised centres of garment production. The latter existed, to be sure, 
but concentrated centres of small-to-medium scale garment producers in districts in Tokyo, Osaka, Gifu, Nagoya, Niigata, Kanazawa and Kyoto for the most part produced work clothes and children's and men's wear. Such garments were assembled in such factories and sold ready-made to the majority of the population by the end of the decade. But in a persistently different pattern, most dress for women continued to be made at home (Nakayama, 1987, p. 461).

This situation contrasted sharply with that in the United States, much to the frustration of Itō Mohei. In 1929 he had founded a successful sewing school, which in the post-war era became a leader in training dress designers for the garment industry. In a 1960 piece in Lady's Forum (Fujin kōron) entitled 'On the Long Wait for ReadyMade', he lamented that whereas the United States ranked first with 95 per cent of women's wear purchased ready-made, followed by Europe at 90 per cent, the total in Japan was merely 40 per cent. A full 60 per cent of women's clothing was made to order. How could it be, he asked, that in a poor country, the majority of women chose the more expensive option? His convincing answer rested in the fact that Japan possessed a new abundance of dressmaking capacity. A vast pool of newly trained home-based dressmakers and seamstresses yielded a balance of quality and cost in the production of ready-made and order-made dress which favoured the home-based practice of sewing (Itō, 1960, p. 62).

The home economics classrooms of the public school system did not offer sufficient hours or depth of instruction to impart more than a basic familiarity with machine sewing, so the primary providers of this expertise were dressmaking schools. The leading institutions had been founded in the 1920s; the most famous was Cultural 
Dress Academy (Bunka Fukusō Gakuin, abbreviated as Bunka). After the war, together with newly founded competitors, these schools expanded at a pace which astonished observers. An extraordinary number and proportion of Japanese women learned to sew in their classrooms, whether to pursue a proper lady's hobby, or to acquire skills useful for a future career as household manager, seamstress, dressmaker, or sewing teacher in her own right. In 1958 the phenomenon inspired Ōya Sōichi to make the exuberant claim that 'no foreigner who observes Japan's Western sewing boom is unsurprised; ...there is no place in the world where schools for Western sewing are as popular as in Japan' (Ōya, 1958, p. 36). ${ }^{4}$ This training was part of the nurturing of the full-time, 'professional' housewife of post-war Japan.

This schooling boom was built figuratively and in some cases literally upon wartime ruins. In 1946, after a one-year hiatus, Bunka was able to recruit a full house of 3000 students within several days of announcing it was re-opening. Running classes in morning, afternoon, and evening shifts to make best use of cramped facilities, enrolment doubled to 6000 in 1947. It reached 10,000 students at a brand new Tokyo campus by 1955, when the largest sewing school in the United States was said to enrol no more than 500 students (Onuma, 1963, p. 150-64; Nakayama, 1987, p. 462; Ōya, 1958, p. 36). Already in 1947400 sewing schools nationwide enrolled 45,000 students; these totals soared to 2400 schools and 360,000 students in 1951 , and as many as 7000 schools with 500,000 enrolled by the mid-to-late 1950s. Roughly 900,000 girls were graduating middle school in each of these years; about one-third of them went on to high school. It

\footnotetext{
${ }^{4}$ Ōya's comparative claim is confirmed indirectly by several of the contributions to Burman, 1999, all of which stress the primary role of apprenticeship, home-based instruction, or home economics classes in ordinary schools (rather than commercial schools) as the route by which British or American women learned to sew in the twentieth century. Especially, see S. Helventson and M. M. Bubolz, pp. 304-5, 30911 .
} 
is clear that attending sewing schools for a time upon graduation from either middle or high school was a post-graduate course that virtually all young women must have thought about and as many as one-half actually followed (Ōya, 1958, p. 37; Sōrifu tōkei kyoku, 1957, p. 436, 438-39).

Whether fabricating for themselves, their family or the market, the mass of students who graduated with relatively strong skills brought to their home sewing a quasi-professional commitment. Ōya brilliantly captured this pragmatic spirit in his 1957 column in the Asahi newspaper titled "the Japanese" (Nihonjin) where he discussed the 'goals of entrants to Western sewing schools'. The energy of the entering students 'is focused not only on the desire to wear fine clothes and look beautiful, nor is it a mindset of faddish imitation of others'. The many young women who saw their studies as a 'prewed' course in bridal training had a sober self-understanding. Some saw the acquisition of sewing skills from one of these schools as a way to move up in the marriage market 'from the prospective bride of a low-ranked clerk in a provincial government office to the spouse of a supervisor or section chief'. Others calculated that their tuition fees would be offset by the ability to fabricate the clothes for a trousseau in the classroom. Still others felt that no self-respecting future wife should let her husband buy his suits off the rack: 'I want to make him a suit myself?. Many others saw their studies in the pre-war spirit of 'self-sufficiency', as a step toward economic independence, as they aimed to work as dressmakers or open their own shops. Ōya concluded that a spirit ranging from realism, practicality, or independence to feminine affection and innocent dreams 'cannot be pigeon-holed as either hardboiled or sentimental. The sound of the sewing machines 
pedalled by the daughters of Japan is dynamic and complex" ("Nihonjin," Asahi shinbun, 13 January, 1957 cited in Nakayama, 1987, pp. 463-64).

Pre-war sewing schools had enrolled both students seeking marketable skills and those looking for a bridal 'finishing' course and household management abilities. The occupational track had dominated, and given the relatively modest skills demanded by the industry at the time, one was employable after a short course of study. Over the postwar years, standards for Western dress and the corresponding skill requirements rose. Without further training, the many women who undertook only the short basic courses at these sewing schools were not prepared for careers as professional dressmakers or designers; for these women, sewing schools served more as bridal than vocational training, especially as skill in Western rather than Japanese sewing came to be seen in conventional morality as the incubator of feminine virtue (Nakayama, 1987, p. 464). But even these women had built a foundation for the acquisition of further skills if needed or desired. With a bit more practice or study, they could fabricate clothes for themselves and their children, demonstrating love of family and saving money into the bargain over the cost of either ready-made or order-made wear. And the significant minority who pursued longer-term, more advanced courses of study indeed graduated with the ability to sew professionally, whether from the home, in a dress shop, or as a factory-based seamstress (Yoshimoto, 2004, p. 31).

This education of masses of women skilled in Western machine sewing and interested to put these skills to use furnishes a key part of the answer to Itō Mohei’s frustrated question: why did the production of order-made clothing continue to dominate the domestic market for women's wear as the 1960s began? He began to answer his 
question by recognising that the cost differential in Japan was relatively small. In the United States, he wrote, even a cheap order-made outfit cost nearly four times as much as a dress off the rack. In Japan, it was only 30 per cent more costly. For Itō, whose school hoped to place graduates in jobs as designers of ready-made wear, the low mark-up resulted from self-exploitation by Western dressmakers who 'simply cannot afford to lose to ready-made clothing, so they make unreasonable efforts to sell cheaply. They live in poverty, and their products are too cheap. If they don't sell cheap, they can't get orders. This is after all a country with excess population and too many competitors' (Itō, 1960, p. 62). There is a kernel of truth to his complaint, but it does not sufficiently consider two aspects of the production system. On the side of industrial producers, ready-made dress had not yet shaken off its reputation for poor quality; those wearing clothes 'off the rack' were dismissed as tsurushinbo, a derogatory term with connotations similar to a racial slur. $^{5}$

On the side of the custom producers, the realm of dressmaking and the ownership of dress shops rested in the hands of women based in the home who were highly skilled, but who viewed their labour as supplemental to a family income. By combining skilled productive labour with the reproductive work of home management they were led, or forced, to work so 'cheaply' that they could outdo the ready-made producers on quality for a modest premium in cost.

\footnotetext{
${ }^{5}$ Tsurushi or 'hang' referred to clothes hanging on racks. The -nbo suffix was a derogatory reference to the person wearing such clothes, also used in ethnic or racial slurs at the time.
} 


\section{Sewing for the market}

These dressmakers and seamstresses were among the many women who contributed to a counterintuitive post-war social trend. That thousands of war widows and other survivors desperately sought to make ends meet through homework in the immediate post-war years is hardly surprising. Less expected is that such home-based production expanded significantly during the era of high-speed growth and surging consumption of the 1950s and 1960s, even as increased numbers of home-workers defined themselves and were viewed as members of the middle class. To make sense of these trends, rather than seeking to separate the daily routine of home-workers into practices that were either consumption or production, we should understand these women as engaged in practices that integrated consuming and producing roles, with the latter dimension relatively hidden as it took place in the home.

The Labour Ministry's Bureau of Women and Children took the lead in documenting this trend. Usefully for our purposes, its surveys defined homework expansively to include those who - so long as they did not maintain a storefront themselves purchased the necessary materials, fabricated the good at home, and sold it directly to a consumer. Surveys of Osaka and Tokyo from the mid-1950s show that at least one member was engaged in home-work at any one time in six to ten per cent of households (Rōdōshō, Fujin Shōnen Kyoku, 1955, pp. 1-3). A more broadly based survey covering most of the nation in 1968 found at least one person undertaking home-work in 12 per cent of all households, with at least one person in another 12 per cent of homes indicating a desire to do such work. In nine per cent of the households surveyed, at least one person not at that moment engaged in home-work had undertaken it at some point in 
the previous five years (Rōdōshō, Fujin Shōnen Kyoku, 1968, pp. 5-6). Put differently, in one out of five Japanese households at least one person had been a home-worker for some portion of the span from 1964 through 1968. Throughout Japan, home-workers supplementing family income numbered roughly 700,000 through most of the 1960s. This figure jumped suddenly and significantly at the end of the decade, to nearly 1.3 million in 1969 and 1.6 million in 1970, reaching a peak in 1973 of 1.63 million homeworkers. Only in the following years did their ranks gradually decline (Rōdōshō, Fujin Shōnen Kyoku, 1976, pp. 2-5).

Needlework was by far the most common form of home-work for women throughout these two decades. In Tokyo in 1954, 'Western sewing' accounted for 16.5 per cent and 'Japanese sewing' for 13.2 per cent of home-workers. These workers, plus those doing piecework for shoes, underwear, hats, gloves, knitting, embroidery and other miscellaneous tasks using sewing machines, accounted for 47 per cent of all homeworkers, and the proportion engaged in one or another sort of needlework had increased to 61 per cent by 1968 (Rōdōshō, Fujin Shōnen Kyoku, 1968, pp. 3, 13).

The women in all these surveys were predominantly wives and mothers who combined home-work with other responsibilities of childcare and household management. In contrast to inter-war surveys, a significant minority of these homeworkers consisted of women in middle-class families. In 1954 Tokyo, a full one-third (34 per cent) of home-worker families were headed by a husband whose occupation was either 'company employee' (21.4 per cent), 'public employee' (6.7) or 'other salaried person' (5.9). Only 12 per cent of the male 'household heads' were factory workers and nine per cent were self-employed. Fourteen per cent of household heads were women, 
either the home-worker herself or her mother. The 1968 survey aggregated the data differently, but the middle-class proportion appears to have been comparable or increased (Rōdōshō, Fujin Shōnen Kyoku, 1955, p. 3; 1955, p. 2; 1968, pp. 8-9).

In sum, over the two post-war decades of rapid economic growth, the overall numbers of home-workers increased, and these women provided an important supplement to family incomes. Home-work was never the monopoly of the poor; already in the inter-war era, a modest group of aspiring middle-class families had been engaged in home-work alongside a larger proportion of the working class (Gordon, 2011, ch. 3, 5). During the high-growth era, the relative weight of lower-middle and middle class homeworkers increased, and their activities most often involved needlework and the sewing machine.

Narratives left by home-workers, both in memoir form and in women's magazines, which delighted in presenting what they called 'true tales' of the economic and social strivings of women, nicely reveal how the roles of consumer and producer overlapped and reinforced each other. The war cast its shadow in one way or another over virtually every home-worker's story, and the Japan Association of War-Bereaved has preserved valuable traces of the self-understanding of such women. In 1963 it published a volume of accounts by 'survivors of the war dead' (Nihon izoku kai, 1963). ${ }^{6}$ Typical was Matsuda Kazuko's tale. Her struggle began with her father's death in Sumatra in January 1945, when she was seven. In 1950 her mother used a government loan available to survivors of the war dead to purchase a sewing machine and cutting table and rent a room to start dressmaking. Crossing the gender line, she learned to tailor

\footnotetext{
${ }^{6}$ The Association has become internationally (in)famous in more recent times for its political role in controversies over the appropriate way for politicians and ordinary survivors to mourn the war dead.
} 
men's clothes, but earnings were hardly enough to support the family. She writes that it was hard to keep up with changing styles and customer taste, and it was also difficult to keep up with housework. In 1953, Kazuko, herself now 15, began to study Western sewing at a sewing school. She helped her mother's business when she could, but they relied on welfare payments to survive. Eventually, however, they managed to build a small home of their own thanks to the survivor pension (Nihon izoku kai, 1963, pp. 9298). Sotozaki Yae's tale of 'Twenty years of difficulties' ended somewhat better. Her husband died in 1939 in China. During the war she worked at home, sewing Japanesestyle clothes, lonely and desperate, crying all the time. A friend suggested she try to support herself with Western sewing, and the local authorities arranged for her to attend sewing school. She was later apprenticed to a local clothing store, given jobs by the sympathetic owner. But eventually she opened her own shop and prospered (Nihon izoku kai, 1963, pp. 253-57).

Comparable narratives appeared frequently in women's magazines of the 1950s, most notably in The Housewife's Companion. These read more like Sotozaki's account than Matsuda's darker story. T.S. from Kyūshū, just returned from overseas, with a husband working in a hospital, bought a sewing machine with a lump sum of compensation for luggage lost en route home, and offers a typical account. To satisfy her customers, she needed to keep up with fashion trends in women's magazines and department stores, and she took care to undercut the order-made prices of the latter by about 30 to 40 per cent. In the end, she happily supplemented her family income to the tune of 2000-3000 yen per month sewing part-time while doing housework (Yoshimoto, 2004, pp. 59-61). 
Such stories were a staple of women's magazines of the time. In addition to such 'true tales', Lady's Club (Fujin kurabu), the most popular competitor to The Housewife's Companion, ran advice columns on 'Home-work in the major cities' or 'How to seek and choose homework', as well as numerous ads for sewing schools and sewing machines. These of course noted the opportunity to earn through home-work as an important reason to learn to sew or buy a machine. The sewing machine sellers similarly filled their inhouse magazines for the sales force, as well as glossier publications aimed at customers, with stories such as that of one Kawaguchi Kinuko who 'managed to save the sum of one million yen simply doing Western sewing home-work' with her reliable Janome machine ('Tatta san zen en no shihon de dekiru yōsai naishoku no tebiki', Janome moodo, Spring 1962, p. 6). And Japan's national broadcaster, NHK, offered a semi-fictional version of these 'true tales' in the 1986 edition of its long-running morning drama, Miyako no Kaze (Breeze of the Old Capital). Such narratives represent tips of an iceberg of home-based needlework, and the editors or producers hoping to sell magazines or win viewers had reason to tilt toward tales of success. The mass of home-workers often laboured in more difficult circumstances, paying a price for their earnings with their health or their time for family or other pursuits. The willingness of so many of these women, dispersed in their homes and carrying out domestic labours as well, to work long hours for modest profits created the supply of order-made dress of quality and cost sufficient to outsell the producers of ready-made women's wear, which so frustrated Itō Mohei.

But to cast these home-based commercial needle-workers as an immiserated underclass of producers is to misread their story. They included both survivors and upwardly mobile strivers. The era of high economic growth coincided with a sharp rise 
in the numbers of home-workers, and the causal links ran two ways. Certainly Japan's 'economic miracle' was in part fuelled by the low-paid labour of these women. But their stories reveal them to be in touch with a world of fashion and glamour; to succeed as a dressmaker one had to read women's magazines and following the latest style trends. These women worked both to fulfil their customers' dreams of a bright new consumer life and in the hope of securing this life for themselves and their children.

\section{Sewing for the home}

However important was the role of home-based commercial sewers in supplying ordermade clothes for the masses, the majority of sewing machine users stitched for themselves and their families. The best statistical evidence of their prominence is provided by the time studies of the 1950s and 1960s. Surveys which found women sewing for two to three hours each day made a point of noting that commercial sewing was categorised separately. Averaged across all households the commitment of women to home-based commercial sewing was a modest fraction of the time spent on family sewing.

Reflecting this allocation of daily time was a shift over historical time in the reasons most women enrolled in sewing school. Acquisition of the skills needed for a future as housewife and home manager came to outweigh vocational training as the reason to enrol (Nakayama, 1987, p. 464). The Yokohama Western Sewing Vocational School was founded in 1927 and renamed after the war for its founder, Iwasaki Haruko, as the Iwasaki Academy. Under her guidance, it became the city's most important sewing school. Ōtsuki Toshiko and Takayama Kazuko were two of Iwasaki's veteran teachers, 
handpicked from among the most talented young students in 1940 and 1948. Decades later, these women recalled that in the late 1940s all the students attended to learn a skill to earn money for themselves or their families. Takayama noted that many were widows with children, and they were desperate. Ōtsuki added 'the students were truly committed and serious. They had a spirit, a resolve born of desperation that was not there before or after. I can never forget those students.' They would start doing homework while still students, taking home their class projects and selling them, remaking and reselling old clothes, and passing on their lessons to others at home. Such students were common as well in the 1950s, in their recollection, but in the 1960s and 1970s students on the prewed track came to dominate. The latter opted for a six month 'short course' which allowed them to cycle through similar courses in cooking, and perhaps flower arranging or tea ceremony, as they or their parents looked for a mate (Author's interview with Ōtsuki and Takayama, 2003).

Monthly magazines and the daily papers played to these graduates in ways that both expanded this swiftly growing audience of domestic sewers at the time and left signs to posterity of their importance. In the 'Family' or 'Women's' pages of daily newspapers, and in monthly magazines for women, patterns and instructions for dresses, blouses and skirts for women, along with all manner of outfits for boys and girls, outnumbered the frequent accounts of home-based sewing for independence and income. The Yomiuri newspaper in late 1952 inaugurated a five-year run of a column devoted to 'Western sewing lessons' (yōsai ka), placed prominently on the paper's 'Women's Page' every two or three days - precisely 581 lessons in all. A sidebar to the first column, 'On the opening of our Western sewing classes', pledged to offer both basic knowledge and 
the latest fashions for the "edification of ordinary women with interest in Western sewing' ('Yōsaika kaisetsu ni tsuite', Yomiuri shinbun, 1 November 1952, p. 5). This feature ended in June, 1957. A more elaborate but less frequent 'This Month's Western Sewing' ran 67 half-page features from January 1960 through August 1965, followed by a weekly 'Yomiuri Western Sewing' column from January 1967 through August 1975 (see illustration). After this, regular sewing columns disappeared from the paper.

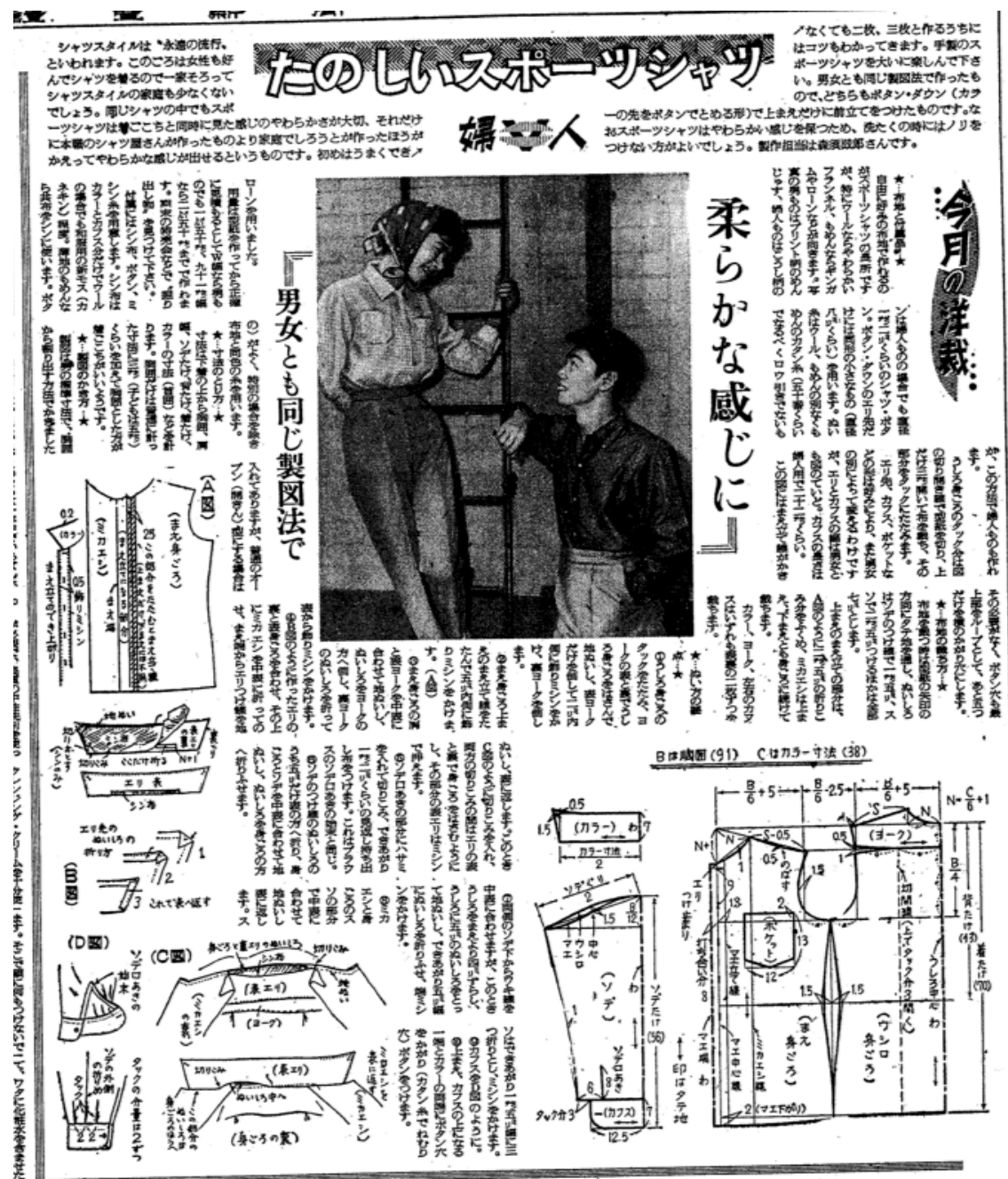

Yomiuri Shinbun 27.2.1960 
This press support for home sewing reflected and reinforced the emergence of Western sewing over Japanese wasai as both practical skill and pre-eminent feminine virtue. As noted above, the 1959 survey of 'free time' made it clear that for as many as one in four housewives sewing was not so much work as a 'leisure' activity. Put differently, one might say that many Japanese women approached their leisure in a remarkably practical or professional spirit. A survey undertaken three years earlier by what the Janome sewing machine company called 'an authoritative research institute in Tokyo' offers nice insight into the self-understanding of home sewers. The survey looked at what it called 'the psychology of buying' to answer the question 'what does a lady want to buy?', with focus on the relative attraction of various 'household cultural goods' ('Gofujin gata wa nani o kaitai ka', in Janome Shanai hō, 1956, p. 11).

The respondents were asked to ponder the following story: 'Akiko desperately wants to buy household cultural goods. She has saved 30,000 yen for this. She goes with this money to a department store and looks around at various goods. An electric washing machine is 25,000 yen. A sewing machine is 26,000 yen. A TV is 80,000 , and a mixer is 12,000 . What does Akiko most want to buy, and why?' The goal of framing the survey in this fashion, it would seem, was to posit a person who owned none of these goods in order to induce the respondent to state her own preference among items she already owned as well as those she did not yet possess. Just over half of the women surveyed (51 per cent) believed that Akiko's greatest desire would be to buy a sewing machine, followed by a washing machine at 41 per cent, and an electric mixer at 4 per cent. Only two per cent of the sample made the television Akiko's first choice. 
The survey interestingly divided these replies into groups of respondents who actually owned particular clusters of goods. Of those who already possessed both sewing and washing machines (19 per cent of all), 49 per cent had Akiko buy a sewing machine and 37 per cent had her buy a washing machine, but of those who did not yet own either of these goods, 69 per cent had her buy a sewing machine, while just 22 per cent had her buy a washing machine. It seems reasonable to see this difference as a measure of the power of marketing and of peer pressure to generate desire for the sewing machine. The lower priority given to it by those who already owned it suggests that a number of buyers were disillusioned once they actually owned a sewing machine; they had probably ended up not using it as much as they expected and with greater difficulty than promised, so they had Akiko opt for a washing machine. Even so, this is only a relative diminution of desire; the preference for the sewing machine over all the other 'cultural goods' is indeed impressive.

The respondents were also asked why Akiko made her particular choice. Among those who had her buy the sewing machine, the vast majority (91 per cent) gave 'usefulness, necessity' as the most important reason, followed by 'preparation for the future' (6 per cent). The remaining handful noted 'just because she wants it' or 'no particular reason'. These investigators probed further into what women meant by 'usefulness' and 'necessity'. The most frequent elaborations were 'it has a greater use value than other household goods' (18 per cent), 'because I can do Western sewing and homework myself' (17 per cent), and 'it is the most needed item for a woman in family life' (10 per cent). The first and last of these comments represented a plurality who saw the mishin as useful primarily in its contribution to family and home life (28 per cent), 
while the second defined 'useful' as a combination of value directly to the family and indirectly through home-work wages ('Gofujin gata wa nani o kaitai ka', in Janome Shanai hō, 1956, p. 11).

The sewing machine overall offered to such women, and to those who in 1959 told government surveyors that they saw machine sewing as a leisure activity, a powerful combination of pleasure and practicality. A woman saved money by sewing for the family rather than buying clothes order-made or ready-made. She took pride at the pleasure shown by children or a husband in their dress. She could make herself attractive as well.

The home-based sewers of early postwar Japan gained satisfaction at their mastery of a skill understood to define feminine virtue and validate a woman as a competent, responsible household manager. The fact that women throughout Japan possessed this high level of skill as part of their 'professional' competence helps explain an intriguing puzzle in their behavior: their reluctance to embrace paper patterns. The American publishers of sewing patterns, Simplicity and McCall, entered the Japanese market with high hopes in the early 1960s, at first glance with good reasons. As Ōya Sōichi had noted a few years before, Japan boasted a reputation as the world leader in both sewing machines per household and, by an even greater margin, the number of students enrolled in sewing schools (Ōya, 1958, p. 36). What could be more promising for sellers of paper patterns that promised easy fabrication of the latest fashions for women and children? Yet, in spite of this seemingly huge pool of ready customers, Simplicity and McCall fared poorly. By the early 1970 s, at a point when 600,000 women were graduating annually from Western sewing schools, the two companies were selling 
only several million patterns a year compared to four hundred million in the United States ('Hoomu yōsai jidai kitaru to iu keredo...', 1973, p. 163; Emery, 1999, pp. 235-53).

The logic and hopes of Simplicity and McCall had failed to take account of the skills and professionalism of the sewing housewife or her young adult daughter. As Ōtsuki and Takayama of the Iwasaki Sewing Academy explained, their students saw these patterns as a short-cut beneath the dignity fostered by their training and skills. It was not that the graduates of sewing schools never used paper patterns. They simply had no need to buy them from Simplicity. Projecting from small-scale drawings, with arithmetic skills and the ability to take their own measurements or those of a child or a customer, they were well able to make their own paper patterns. Only the widespread possession of this ability can explain why mass-circulation dailies would devote precious space several days each week to the sort of small-scale drawings shown in the illustration above. Indeed, teaching the skills to do this was at the heart of the sewing school curriculum. Ōtsuki and Takayama stressed the professional consciousness of homesewers: they considered it a source of pleasure and of pride to create clothing from their own materials and ideas (Author's interview with Ōtsuki and Takayama, 2003).

\section{Conclusion: the era of dressmakers and consumers}

Whether used for home-work or family wardrobes, the sewing machine in post-war Japan (and elsewhere as well, I suspect) was not a tool which primarily immiserated its users, as described and predicted by Karl Marx; nor was it a means to protect local traditions and live a simple life, as claimed by Mahatma Gandhi (Marx, 1921, pp. 516-18; Gandhi, 1960, ch. 7). Rather, it connected women and families to the modern consumer world. It 
offered them hopes of climbing the social ladder as the economy surged. It was a tool of class integration more than division, as it helped build the cultural hegemony of middleclass life-ways in the high-growth era. And, as women moved between the roles of home-worker-housewife and full-time housewife, it linked their identity as income earners to that as responsible consumers and professional home managers.

The lifespan of the regular sewing column in the Yomiuri ran from 1952 to 1975. These years mark the rough chronological bounds of two related eras: the time of Japan as a nation of dressmakers and the time when the professional housewife reigned most securely as the ideal for women. Her position as the natural exemplar of adult womanhood was never unchallenged; periodic 'housewife debates' erupted in public life across these years, and we can be sure many private conversations offered diverse answers to the question of how women might best lead their lives (Ueno, 1982; Fujii, 2002, pp. 15-22). Even so, a trans-war social and cultural formation runs from the 1920s across the war and through the high-growth era, marked in terms of women's roles by the prominence first of the pre-war to wartime 'housewife' (shufu), unmodified, and thence to the 'professional housewife', defined in part by well-honed skills in managing and fabricating the family wardrobe, as well as managing the family as consumer of massproduced goods of all kinds.

In terms of dress, this era ended with the ascendance of ready-made women's wear. The practice of women sewing at home for their family members began to decline in the 1960s (Nihon hōsō kyōkai, 1970, pp. 11-12, 1172). From an all-time peak in 1969, the domestic sale of sewing machines began a long slow decline. Articles began to appear in the press in the early 1970s lamenting that so many sewing machines sat 
unused at home. All told, from the 1970s onward, the place of sewing in the daily routines of women diminished greatly. In the realm of cooking a similar shift took place, a bit later and more gradually, toward reliance on prepared foods. Although most married women, including the increasing numbers who worked outside the home, retained the role of household manager, they acted less as the fabricators or processors of that which the family consumed and more as the purchasing agent who managed the acquisition of all manner of goods and services. In the realm of family and daily life, this shift marks the end to an era.

Even so, the professional housewife has had a remarkably long afterlife. Throughout the second half of the twentieth century and into the early twenty-first, Japan ranked just after South Korea at the top of the industrial capitalist world in the depth of its 'M-curve,' the graphic representation of the proportion of women who leave the job market during years of childbirth and childrearing (Brinton, 1993, p. 29). ${ }^{7}$ In explaining the endurance of the full-time housewife both as social ideal and in experience, negative incentives, such as an income tax system which penalised families with two full-time wage earners, are important to note. But to fully understand this endurance, one must recognise as well the positive social validation for the work of a 'professional' housewife, including her management of the family wardrobe. Of course she was not created pure and simple by the sewing machine and its associated skills, but sewing was significant among the several realms of endeavour that brought a wider consumer economy and culture intimately into the home, offering a powerful connection to that wider world and affirming her role in managing those links.

\footnotetext{
${ }^{7}$ For more recent comparative data, see the category of 'labour force statistics by sex and age' at http://stats.oecd.org/index.aspx. Accessed August 10, 2009.
} 


\section{Bibliography}

M. Brinton (1993) Women and the Economic Miracle: Gender and Work in Postwar Japan (Berkeley: University of California Press).

B. Burman (1999) The Culture of Sewing: Gender, Consumption, and Home Dressmaking (Oxford: Berg).

J. S. Emery (1999) 'Dreams on Paper: A Story of the Commercial Pattern Industry', in B. Burman (ed.) The Culture of Sewing: Gender, Consumption, and Home Dressmaking (Oxford: Berg).

H. Fujii (2002) Sengyō shufu wa ima: tayōka to koseika no naka de (Tokyo: Minerubua Shobō).

M. Gandhi (1960) All Men are Brothers: Life and Thoughts of Mahatma Gandhi as Told in His Own Words, Krishna Kripalani (ed.) (Navajivan Mudranalaya, Ahemadabad: Jitendra T. Desai) (accessed at http://www.mkgandhi.org/amabrothers/amabrothers.htm on June 10, 2010).

'Gofujin gata wa nani o kaitai ka' (1956) in Janome Shanai hō, vol. 1, no. 2, p. 11.

A. Gordon (2003) Interview with Ōtsuki Toshiko and Takayama Kazuko.

A. Gordon (2011) Fabricating Consumers: The Sewing Machine in Modern Japan (Berkeley: University of California Press).

S. Helventson and M. M. Bubolz (1999) 'Home Economics and Home Sewing in the United States, 1870-1940', in B. Burman (ed.) The Culture of Sewing: Gender, Consumption, and Home Dressmaking (Oxford: Berg).

'Hoomu yōsai jidai kitaru to iu keredo...' (24 March 1973) Josei jishin, p. 163.

M. Inoue (2001) Yōfuku to Nihonjin: kokumin fuku to iu moodo (Tokyo: Kōsaidō shuppan).

M. Itō (20 May 1960) 'Redi meedo taibō ron', Fujin kōron,

Kawasaki rōdō shi hensan iinkai (1987) Kawasaki rōdō shi (Kawasaki).

K. Koizumi (2000) Shōwa no kurashi hakubutsukan (Tokyo: Kawade shobō). 
W. Kon (1967) Janpaa o kite 40 nen (Tokyo: Bunka fukusō gakuin shuppan kyoku).

Y. Kunihiro (2001) Shufu to jiendaa (Tokyo: Shōgakusha).

K. Marx (1921) Capital, Volume I, Chapter 15, Section 8e (New York: Charles H. Kerr and $\mathrm{Co})$.

C. A. Mason (1949) 'Le budget-temps de la femme à Londres dans les classes laborieuses', Population (French edition), 4:2, p. 372.

Mishin kōgyō (April 1954), 'Mishin no fukyū jōkyō to kongo no juyō ni kan suru hito kōsatsu'

C. Nakayama (1987) Nihon fujin yōsō shi (Tokyo: Yoshikawa kōbunkan).

Nihon hōsō kyōkai, ed. (1970) Kokumin seikatsu jikan chōsa (Tokyo: Nihon hōsō kyōkai).

Nihon izoku kai, ed. (1963) Ishizue: Senbotsusha izoku no taiken kiroku.

Nihon mishin kyōkai, ed. (1961) Nihon mishin sangyō shi (Tokyo: Nihon mishin kyōkai).

Nihon tōkei kyōkai, ed. (1987) Nihon chōki tōkei sōran v.1 (Tokyo: Nihon tōkei kyōkai).

E. Ochiai (1994) 21 seiki kazoku e: kazoku no sengo taisei no mikata, koekata (Tokyo: Yūhikaku).

J. Ōnuma (1963) Bunka fukusō gakuin yonjū nen no ayumi (Tokyo: Bunka fukusō gakuin).

S. Ōya (1958) 'Nihon no kigyō: Doreme', Shūkan Asahi, vol. 63, no. 4,

Rōdōshō, Rōdō kijun kyoku (September 1976) Kanai rōdō no genjō (Tokyo).

Rōdōshō, Fujin Shōnen Kyoku (1968) Naishoku shūgyō kihon chōsa hōkoku. (Tokyo).

Rōdōshō, Fujin Shōnen kyoku, ed. (1959) Shufu no jiyū jikan ni kansuru ishiki chōsa (Tokyo).

Rōdōshō, Fujin Shōnen Kyoku (1955) Katei naishoku no jitsujō: Osaka shi chūkan hōkoku (Tokyo)

Rōdōshō, Fujin Shōnen Kyoku (1955) Katei naishoku no jitsujō: Tokyo 23-ku (Tokyo).

Rōdōshō, fujin shōnen kyoku (1952) Kōjō rōdōsha seikatsu no chōsa (Tokyo). 
Sōrifu tōkei kyoku, ed. (1957) Nihon tōkei nankan, 1957 (Tokyo: Nihon Tōkei kyōkai).

J. Stoetzel (1948) 'Une étude du budget time de la femme dans les agglomerations urbaines', Population vol. 3, no. 1, 52-56.

'Tatta san zen en no shihon de dekiru yōsai naishoku no tebiki' (Spring 1962) Janome moodo

C. Ueno (1982) Shufu ronsō o yomu (Tokyo: Keisō shobō).

J. Vanek (1973) 'Keeping Busy: Time Spent in Housework, United States, 1920-1970', (University of Michigan, PhD dissertation, Sociology).

S. Vogel (1978) 'The Professional Housewife: The Career of Urban Middle Class Japanese Women', Japan Interpreter vol. 12, no. 1, pp. 16-43.

K. Yoshida (Extra issue of March, 1955) 'Monpe kara A line made: fukusō fūzoku no sengo 10 nen', Bungei shunjū, pp. 140-42.

Y. Yoshimoto (2004) 'Hanabiraku yōsai gakkō', in K. Koizumi (ed.) Yōsai no jidai (Tokyo: OM Shuppan).

Y. Yoshimoto (2004) 'Onna no jiritsu o sasaeta yōsai', in K. Koizumi (ed.) Yōsai no jidai (Tokyo: OM Shuppan). 